\title{
Opposing Worldviews: A New Perspective on Ernesto “Che” Guevara's Failure in the Congo
}

\author{
Amy J. King
}

Todos los hombres libres del mundo deben aprestarse a vengar el crimen del Congo. Ernesto Guevara1

\section{INTRODUCTION}

This article serves two purposes: 1) to reexamine Western portrayals of African and Hispanic history, and 2) to depict Che Guevara's failure in the Congo through a more inclusive scope of cultural misunderstanding. Guevara's experience in the Congo is often overshadowed by his success in Cuba and even his death in Bolivia. His revolution to liberate the oppressed Congolese from imperialist intervention has been a source of inquiry for many historians during the past five decades. Many scholars attribute his defeat to a variety of political and economic factors including, but not limited to, regionalism in the Congo, conflict between Congolese and Cuban rebel forces, insufficient resources, and a lack of a unified vision. Even though these aspects clearly played a critical role, this essay will theorize that opposing worldviews of Cuban revolutionary and local forces were the pivotal factor leading to divisiveness among the rebel forces in the Congo during the 1960s and Guevara's ultimate failure in Africa.

\section{HISTORY OF THE CONGO}

To understand Che's motives for inserting himself and his communist revolution in Africa, it is crucial to contextualize the history and the political climate in the Congo. What is now referred to as the Democratic Republic of the Congo, or the DRC, has been recognized by several names in the past. The Kingdom of the Kongo was named the Congo Free State, after being designated as King Leopold II of Belgium's private property. The Congo Free State "was a Belgian colony for many years, during which time its mineral wealth was controlled by Belgian, British, and American consortia" (Villafaña 3). At the turn of the twentieth century, Belgium annexed the country as one of its colonies, renaming the territory the Belgian Congo. Belgian colonial rule was brutal and cruel. As a result, "Anticolonial nationalism rapidly developed in the 1950s, challenging the colonial order [...] the critical episodes that so shook a once-invincible colonial administration [...] were the leaderless, spontaneous convulsion of the January 1959 Kinshasa (Leopoldville) riots and the spread of civil disobedience in such key regions as Lower Congo, Kwilu, and Maniema" (Clark 14).

On June 30, 1960, the Congo won its independence from Belgium. During this period the country became known as the Republic of the Congo-Leopoldville (not to be confused with the neighboring French colony, the Republic of the Congo-Brazzaville). In Cold War in the Congo, author Frank R. Villafaña relates that the "political situation in Congo immediately after independence was certainly in disarray, but with Lumumba's election win and his appointment as Prime Minister, it looked as if circumstances would improve. Lumumba's assassination, six months later, instantly turned disarray into chaos" (17).

Several short-term governments sprang up and died down before Joseph Mobutu, whom Lumumba had appointed chief of staff of the Congolese army, successfully instigated a coup. At the time there was speculation of the United States' and Belgium's involvement in Mobutu's rise to power, especially considering the new leader's stance of anti-communism during the Cold War, which was confirmed once more at the turn of the century when the Belgian Parliament declared its country responsible for Lumumba's execution. During the political chaos in the Congo in the early 1960 , there was an epidemic of progressive rebellions mainly in the central and eastern areas of the country. One of these rebellions to the north, led by Nicolas Olenga, captured Stanleyville-Kisangani and established the progressive People's Republic of the Congo (Gott xvi).

With the Cold War well under way, the United States perceived these rebellions as a threat to democracy and sent delegates, troops, weapons, and financial support to aid in Kasavubu and Tshombe's struggle against communism. The U.S. also initiated several undercover operations during this time, attempting to stomp out communism in Africa. Several African countries, such as Algeria, Egypt, Ghana, Guinea, Mali, Tanzania, and Zanzibar, came to the aid of the rebel forces, also referred to as the "Lumumbist left" and 
"expressed their opposition to what looked like the re-imposition of colonial rule in the Congo - with Tshombe as a black puppet leader" (xviii-ix). Therefore, when Algeria reminded Cuba of their help in its (failed) 1962 guerrilla movement in Argentina, Cuba responded by offering reciprocal assistance to their allies in the Congo.

\section{CHE'S INVOLVEMENT IN THE CONGO}

This is the chaotic and hostile political climate that the Congo was experiencing when Ernesto "Che" Guevara, with Cuban support, decided to take his communist revolution to Africa. Guevara's political and economic agenda should not be analyzed separately from his personal history, for the latter greatly influenced the former. Ernesto "Che" Guevara was born in Buenos Aires in 1928. He studied medicine taking multiple leaves from the university to travel throughout Latin America. He later joined the revolutionary cause in Cuba led by Fidel Castro in 1955. In 1965 Guevara took his guerrilla revolution to the Congo, which resulted in irreparable failure. After a period of recuperation and reflection in Prague during 1966, Guevara decided that Bolivia was the next appropriate country to begin his continental revolution. His time in Bolivia served as proof of his total dedication to the revolutionary way of life and also marked its brutal end; Guevara was executed on October 9, 1967 by the Bolivian army with the support of the United States CIA. ${ }^{2}$

Guevara's experiences throughout Latin America and in Africa greatly shaped his communist revolutionary ideology. Witnessing the impoverished populations' living conditions in several different countries due to oppression from capitalist and imperialist nations solidified Guevara's beliefs and pushed him into the global political spotlight. The most significant event being the United States' involvement in overthrowing the progressive Guatemalan government of Jacobo Arbenz in the year 1954, through which he developed an "implacable hatred of the United States" and imperialist nations alike (Gott xii). Guevara's "concern for the poor and his later belief that their lot could be improved through violent revolution, fueled his actions for the rest of his life" (xi-ii). In the 1964 United Nations General Assembly in New York, Guevara gave an impassioned speech on the matter, claiming:

Quería referirme específicamente al doloroso caso del Congo, único en la historia del mundo moderno, que muestra cómo se pueden burlar con la más absoluta impunidad, con el cinismo más insolente, el derecho de los pueblos. Las ingentes riquezas que tiene el Congo y que las naciones imperialistas quieren mantener bajo su control son los motivos directos de todo esto. En la intervención que hubiera de hacer, a raíz de su primera visita a las Naciones Unidas, el compañero Fidel Castro advertía que todo el problema de la coexistencia entre las naciones se reducía al problema de la apropiación indebida de riquezas ajenas, y hacía la advocación siguiente: «cese la filosofía del despojo y cesará la filosofía de la guerra.» Pero la filosofía del despojo no sólo no ha cesado, sino que se mantiene más fuerte que nunca y, por eso, los mismos que utilizaron el nombre de las Naciones Unidas para perpetrar el asesinato de Lumumba, hoy, en nombre de la defensa de la raza blanca, asesinan a millares de congoleños. ("Patria")

In this famous "Patria o muerte" speech, given before his involvement in the Congo, Guevara illuminates many of the global injustices that were being caused and sustained by imperialist nations around the world. He continues by calling into question the role of the United Nations, the United States, and Belgium in Congolese affairs. He challenges Tshombe's leadership and alleges that Belgium's actions in the Congo are comparable to Hitler's actions in Belgium just two short decades earlier. Che adhered to "a new Marxist humanism" and argued that "genuine Marxism does not exclude humanism: it incorporates it" (Löwy 6). Guevara himself stressed the importance of "a Marxist, socialist system which is coherent, or nearly so, in which man is placed at the center, and in which the individual, the human personality, with the importance it holds as an essential factor in the revolution, is taken into account" (Guevara "Il piano"). For this reason, Guevara felt the need to extend his revolution to Africa, more specifically to the Congo.

Months prior to the launch of his campaign in the Congo, Guevara travelled throughout Africa meeting with several politicians and diplomats. According to Paco Ignacio Taibo II, "el Che se desplazó a toda velocidad por el continente, entablando relaciones con los nuevos líderes progresistas, discutiendo con dirigentes de los grupos de liberación, hablando con estudiantes y periodistas [...] saltando de aeropuerto en aeropuerto, manteniendo conversaciones con los presidentes de los países claves en el movimiento anticolonial" albeit Guevara himself claimed that "no estaba nada decidido" (577, 601). During this time, Guevara was exposed to a more authentic African experience. Even though he may not have decided to bring the revolution to the Congo in that very moment, Cuba's plan for intervention was already underway.

When Guevara finally arrived in April of 1965 with the idea of continuing the anti-imperialist revolution in the Congo, he entered the continent using the name Ramón Benítez, and was later referred to by his nom de guerre, Tatu. Che and his men, along with four other rounds of troops that would be sent from Cuba by the end of April, began training in the Congolese territory west of Lake Tanganyika. They ambushed the roads between the towns of Bendera and Albertville controlled by Captain Hoare, who was loyal to Mobutu (the head of the Congolese army), and his white mercenaries from southern Africa. The Cubans' small military feats were detached from any major political 
advances and Kasavubu (the president) and Tshombe (the prime minister) maintained control of the country.

Che Guevara and the Cuban forces were only in the Congo for nine months, the first couple of months were spent waiting for troops and training them upon arrival. In November of 1965, Guevara abandoned the revolutionary cause and retreated to Havana (after a temporary stay in Prague) with what remained of his troops. His retreat was spurred by Kasavubu dismissing Tshombe from his position as prime minister and replacing him with Kimba, with whom the Organisation of African Unity was less opposed. This change in leadership would later sabotage Che's support in Africa, leading to a compromise between Kasavubu and the Congolese rebel forces' leadership. With no internal African support, Fidel Castro's public denouncement of Guevara, and China's unwillingness to intercede, Che made the call to withdraw his troops and his revolution from Africa. This defeat defined the rest of Guevara's political career, and as Agustín Monzón reveals in his article "El Che Guevara murió en el Congo," the adventure of Che in the Congo is "[u]n fracaso que determinaría de forma casi irremisible sus siguientes pasos hasta su trágico final, casi dos años después, en las estribaciones de los Andes."

\section{REASONS FOR FAILURE}

Written after his withdrawal from Africa, during a period of reflection and retrospect, Guevara begins his Pasajes de la guerra revolucionaria: Congo by stating, "Esta es la historia de un fracaso." Why were the Cuban forces unable to promote lasting political change in the Congo, but later successfully helped construct the Guinean State and secure Namibia's independence? How is it that Che, who played a critical role in the success of the Cuban Revolution, could fail so terribly in the Congo? Many scholars attribute his defeat to a variety of political and economic factors including, but not limited to, regionalism in the Congo, conflict within the rebel forces, insufficient resources, and a lack of a unified vision. These factors affected every level of the revolution in the Congo, starting from the bottom up.

\section{Cuban Troops}

A documentary released in 1997 interviewed the surviving Cuban soldiers who fought alongside Guevara in the Congo. One of his fellow soldiers reveals the Cubans' attitude towards Che upon reminiscing:

La orden era $[\ldots]$ comer donde come él, dormir donde duerme él y morir donde muere él. Bueno, a mí eso me caía mal, ¿no? Porque el primer día cuando yo fui a coordinar con Tatu sobre las horas de clase, a mí me cayó mal por la forma penetrante de mirar a un tipo... eh... con una mirada tipo irónico. Esa cosa, y me cayó mal. Bueno... soportar ese blanco..." ("Tatu” oo:15:23-50)

This video highlights the internal relations between Guevara and the Cuban troops. From the beginning, there was division at the most basic level. It is important to keep in mind that the first forces sent to the Congo consisted solely of black Cubans as to not draw suspicion. However, this plan backfired by casting Guevara as an outsider within his closest, most loyal group of soldiers. Nonetheless, the Cubans faced another issue that was far more fundamental. Not only were they wary of their leader, but they also lacked faith in the success of their mission. The select group of Cuban soldiers began their training months prior back in Cuba, not knowing where they would be sent. When they set off for the Congo, by way of Tanzania, they were still unaware of who would lead them in their operation. The Cuban soldiers were constantly in the dark and completely unprepared for the Congolese terrain that they were to maneuver. The troops' doubt is made clear when Guevara explains, "En la reunión de partido insistí una vez más en la necesidad de que me apoyaran para crear un ejército disciplinado, un ejército ejemplo. Pregunté a los presentes quiénes creían en la posibilidad del triunfo y solo levantaron la mano de Moja y Mbili y los dos médicos llegados últimamente" (Pasajes 176). The Cuban forces lacked preparation, motivation, and confidence.

In his article, Agustín Monzón questions Guevara's true motives for inserting himself and the Cuban forces in the Congo when he insists that "La lucha en África era la vía de escape de un hombre que, tras contribuir decisivamente a la victoria de la Revolución en Cuba, había sentido la frustración del fracaso en su tarea como ministro de Industria en el nuevo régimen de Fidel Castro, que fue desechando una a una sus principales tesis políticas." Although many believe the rather romantic notion that Guevara became involved in the Congo for the betterment of humanity and to sever the imperialist ties of an oppressed nation, Monzón points out another valid motive: Guevara's political presence in Cuba would forever be limited under Fidel Castro's rule. Africa offered Guevara a fresh start at another revolution with less oversight. Nevertheless, Cuban troops' internal issues and that of their leader were only one factor leading to their inevitable failure.

\section{Congolese Forces}

On the other hand, the Congolese forces experienced even greater division among themselves. While planning the revolution in the Congo, Che "había subestimado la importancia de las fracturas tribales en territorio africano" (Monzón). The rebel forces in the Congo were already divided before Cuba's arrival. A variety of leaders and tribes controlled the lands in the center of the country as well as in the east. Not only did Guevara find difficulty in melding 
Cuban and Congolese soldiers, but more importantly he was unable to unify the local rebel forces that were already fighting and securing territory in the Congo. Guevara's perceived whiteness was also an issue for the Congolese troops. Although one of his soldiers denies any racial prejudices on behalf of the revolutionary's leadership, he ironically reveals how the enemy was able to divide the troops by discrediting Guevara's personality solely based on the color of his skin. The soldier states, "Había negros en su contingente y no es posible que él sea racista con otros negros, solamente, porque eran congoleses. Son las típicas historias utilizadas con el fin de desacreditar... a un movimiento, a una personalidad. Siempre recurren a este tipo de estratagema"4 ("Tatu" o0:28:06-29). Although his Cuban soldiers claim that these accusations were false, they clearly contributed to the Congolese impression of Guevara and spurred mistrust among the rebel forces.

There was also a rift between Cuban troops and Congolese forces. Guevara himself expressed that "Lo fundamental era lograr la unidad entre congoleses y cubanos, tarea difícil" (Pasajes 177). The unification of Cuban and Congolese forces never came to fruition and neither did their revolution. Instead of fighting the Congolese government and their imperialist counterparts together, the revolution was spread too thin throughout the country. Not only was the revolution fighting the enemy on too many fronts, but it was also fighting against itself.

\section{Leadership}

Guevara's failure in the Congo has also been attributed to problems within the leadership of both the Cuban and the Congolese revolutionary forces. When Che entered eastern Congo in April of 1965, Congolese rebel leadership was unaware of his arrival. In "El Che en el Congo: 'La historia de un fracaso"," Marc Jourdier reveals how "Por motivos de seguridad, el Che Guevara no había develado a los dirigentes de la revolución que formaría parte del destacamento enviado por Cuba. Una vez en el Congo, avisa a Kabila, con quien había hablado unos meses antes en Brazzaville durante una gira africana, para que venga a verlo." Guevara's presence in the Congo was unknown to rebel leaders and by not informing them of his arrival he denied them the opportunity to organize the rebel forces in advance. Two months passed before Kabila and Guevara met face to face. In his memoirs of the Congo, Che reveals how his relationship with Kabila gradually unraveled. He depicts Kabila as less than committed to the revolutionary cause and makes references to his drinking habits (Pasajes 86-7). Disagreement and lack of communication between Guevara and Kabila stalled the revolution's progress and permitted the enemy enough time to learn of Guevara's presence in the country, allowing them to reevaluate their plans and modify their tactics.
There were also disputes among the rebel forces and "their leaders, including Kabila, [who] were regarded as strangers - or more pejoratively still as “tourists"” (Seddon). Few Congolese leaders had any contact with the local tribes before Lumumba's unconstitutional dismissal from office, which led them to take up arms against the local government. The sudden appearance of such leaders, like Kabila, were viewed skeptically by the local Congolese troops.

\section{Support}

Many odds did not favor the revolution in the Congo. Other examples include the Congolese government's abundance of Western support, the rebels' lack of external allies, language barriers, and the Organisation of African Unity's willingness to compromise. Interestingly, it was Fidel Castro publicizing Che's farewell letter in October of 1965 that alienated Guevara from his most loyal supporter and led him to withdraw his troops the following month. In the letter, Guevara states:

I formally renounce my posts in the leadership of the Party, my post as Minister, my rank as Major, my status as a Cuban citizen. Nothing legal binds me to Cuba, only ties of another kind that cannot be broken, as can official appointments [...] I can do what is forbidden to you because of your responsibility to Cuba, and the time has come for us to separate [...] I say once more that I free Cuba of any responsibility. ("Farewell")

Guevara wrote this letter to Castro in April of 1965, severing political ties with Cuba. However, he was upset that it had been disclosed to the public so readily. In a revolution that Guevara estimated would take five years to achieve, he was morally defeated when Castro published his letter after a mere six months. Che suddenly found himself in a chaotic revolution without the support of his close friend and advocate.

\section{A NEW PERSPECTIVE}

Historians have theorized the numerous factors that led to Guevara's withdrawal from the Congo. This paper asserts that these factors can be simplified by arguing that Che's vision for the Congo failed due to a difference in worldviews. As Karanja Keita Carroll explains in his article "Africana Studies and Research Methodology: Revisiting the Centrality of the Afrikan Worldview," the fundamental difference among cultures around the globe is the way they view the world. According to Keita Carroll, "the Afrikan worldview refers to a universal orientation and interpretive reference point that Afrikan people share" and clarifies that this "should not suggest a static means of interpretation 
across the Afrikan world, however it does suggest that there are common interpretive processes that Afrikans utilize in their attempts at understanding a given phenomenon, and thus reality" (6). Keita Carroll elaborates upon the work of Vernon J. Dixon who distinguishes the African-oriented versus the Euro-American-oriented worldviews. Although Dixon places the ideology, axiology, ontology, and epistemology of these two worldviews in direct opposition, it is not unusual to see traces of Euro-American-oriented worldviews in African-oriented worldviews and vice versa. Differing worldviews may still share similar philosophies. Shared philosophies and characteristics do not undermine worldviews, but instead make them more diverse and inclusive.

National identity theories are often linked to ideas of race. Throughout Latin American history, we observe a shift from beliefs such as las castas (castes) to mestizaje (miscegenation) to multiculturalismo (multiculturalism) in the 1980s. These theories of racial purity, social hierarchy, and ethnic pluralism have been used to define national identities in Latin America from colonialism to present day. Similarly, several theories emerged surrounding ethnic and national identities in Africa. Philosophies including Négritude, Pan-Africanism, Afrocentrism, and Afropolitanism originated during the twentieth and twenty-first centuries (Balakrishnan "Afropolitanism" 575-76). On both continents we witness a gradual conceptual shift regarding national identity, from colonial nationalism, to nativism, to (most recently) racial multiplicity and, in some cases, identities separate from race. Specifically, the Afropolitan approach incorporates the coexistence of differing ethnicities through tolerance. Afropolitanism is the belief that these differences and interactions are the common glue that holds the African continent together (Mbembe and Balakrishnan 31). Although Afropolitanism has been criticized for "shifting away from a race-based epistemology... to engage in universalist non-racial thought from an African perspective," Mbembe argues that it is possible to recognize the deep, rooted impact of colonialism, slavery, and African diaspora while also focusing on "the paradigm of itinerancy, mobility, and displacement" that forges a common cultural bond among those who consider themselves African (Balakrishnan, "The Afropolitan Idea" 7, 58). According to Mbembe, Africanness is not defined solely through opposition, cultural purity, or the role in Africa around the world; it is also defined by the presence and imprint of the rest of the world's history on the African continent:

Our way of belonging to the world, of being in the world and inhabiting it, has always been marked by if not cultural mixing, then at least the interweaving of worlds, in a slow and sometimes incoherent dance with forms and signs that we have not been able to choose freely but which we have succeeded, as best we can, in domesticating and putting at our disposal. (59)
So, how then are we to discuss differing worldviews and cultural and ethnic pluralism without falling into the temptation of dichotomies as Mbembe suggests? And how does this relate to Guevara's experiences in the Congo? This paper relies on the interplay between these two theories, Afropolitanism and the Afrikan Worldview. They complement each other, filling in what the other lacks. Afropolitanism broadens the tendency towards dichotomy often noted in the Afrikan Worldview theory. In contrast, the African Worldviews authenticate African cultural capital, which Afropolitanism is often criticized for undervaluing.

Theories on race and diaspora are complex and are under constant scrutiny and modification; for this reason, I will attempt to avoid oversimplification. Che Guevara's worldview cannot accurately be described as solely "European-oriented." His role in Africa is distinct from that of the colonizers and imperial powers; it is more complex. We cannot contain his role inside a tidy box and label it with just one theory. Nonetheless, we must confront these differences in worldviews.

\section{Opposing Worldviews}

The previously mentioned reasons for Guevara's unsuccessful revolution do not provide the full narrative of Guevara's time in the Congo. My objective is to unify these reasons, expand upon them, and fill in the gaps. Analyzing opposing worldviews is key to presenting a more holistic version of these events. To do so, I will rely on the theory of Afropolitanism and Afrikan Worldviews for two reasons. First, we must deploy Afropolitanism in this case because there is not just one African worldview. Borrowing the plurality of Africanness from the Afropolitan theory, all worldviews held by those who have ties to African experiences are valid and can be considered "African." Second, while contrasting worldviews we must remember that Guevara's revolution in the Congo is both an African and Hispanic phenomenon. These dual perspectives have yet to be analyzed authentically. Past research tends to portray Guevara's time in the Congo from Western perspectives, which does appropriately situate this event in world history.

Both the local Congolese troops' and the Cuban forces' worldviews affected the outcome of this event. Rather than pointing out Cuban or Congolese shortcomings, we should analyze the relationship between these two parties through the lens of Afropolitan (or, inclusive and diverse) worldviews. In the case of Che in the Congo, a disconnect existed between the Cuban forces and the local Congolese rebels. This detachment spawns from a clash among differing worldviews and is the cause of many of the previous reasons for failure, such as conflict between Congolese and Cuban rebel forces, lack of a unified vision, and insufficient resources and support. 
Before giving specific examples of differing worldviews, we must first generally compare the Cubans' worldviews and the local Congolese's worldviews. There are several factors within a community that contribute to its worldview. Here we will focus on four main factors according to Karanja Keita Carroll: ideology, axiology, ontology, and epistemology.

The principal difference between Guevara and the local Congolese citizens was their ideologies. Che entered the Congo with the dream of continuing the communist revolution on another front. To him, his ideals aligned with the needs of the rebels with whom he would fight alongside. Che explicitly clarified to Kabila that Cuban troops were present to serve the needs of the African leaders in their attempt to remove Kasavubu and Tshombe from power, eliminating imperialist intervention once and for all. Having witnessed the communists' success in Cuba, the locals hoped that their support would lead them to victory as well.

Many African worldviews' "axiological basis is grounded in cooperation and collective responsibility; corporateness and interdependence" (Keita Carroll 10). Even though these tenets align with communist and Marxist beliefs, Che and the Cuban forces' axiology differs in that the orientation of his values is more closely related to "Doing, Futuretime, Individualism and Mastery-over-Nature" rather than the Afrikan "Being, Felt-time, Communalism and Harmonywith-Nature" (Dixon qtd in. Keita Carroll 10). According to Michael Löwy's research entitled The Marxism of Che Guevara, Marxism ought "to serve as a guide to action" (6). Guevara's Marxist ideology determined that his axiology would value action, future change through revolution, and the role of the individual over everything else, contrasting with Afrikan worldviews.

The ontological difference between Che and the Congolese forces is rooted in the way both parties view the very nature of beings and reality. African ontology "suggests that the nature of reality and being is spirit/energy," which should not be mistaken for religion (Keita Carroll 15). Dona Richards explains African spirituality, which contrasts with Euro-American and European emphasis on the material, by stating:

When a group of people share a common heritage, a common set of experiences and a common culture, an emotional bond is created between them [...] The idea of "spirit" is especially important for an appreciation of the African-American experience. "Spirit" is, of course, not a rationalistic concept. It cannot be quantified, measured, explained by, or reduced to, neat, rational, conceptual categories as Western thought demands. "Spirit" is ethereal. It is neither "touched" nor "moved", "seen" nor "felt" in the way that physical entities are touched, moved, seen and felt. These characteristics make it ill-suited to the mode of European academia and to written expression. (249)
Guevara's Marxist ideology and resulting economic beliefs were strictly focused on material reality. His theories vastly contradict the existence of spirituality, let alone that the most basic level of reality is spiritual. Che's inability to train, unify, and direct the Congolese tribes can be ascribed to his naivety regarding their ontological perspectives of the world.

In contrast, Che's worldview was similar to the Congolese worldviews on an epistemological level. In EuroAmerican worldviews "the knower will distance him/herself from the phenomena they are attempting to know. Within Afrikan worldviews, the knower attempts to be a part of the phenomena s/he is attempting to know" (Keita Carroll 11). Guevara's Marxist values, which call upon the individual to act towards true liberation, and his eagerness to join the Congolese troops in their fight against imperialism appear to lean slightly towards African epistemological approaches. He spent months travelling throughout Africa to gain knowledge of the political and economic situation in the Congo. His role in the Congolese revolution reflects the African epistemological value of inserting oneself in a specific phenomenon for better understanding.

\section{INDICATIONS OF A BIGGER PICTURE}

Several sources exist documenting Che's time in the Congo. There are government documents, communications between allied supporters, speeches, and several photos. Journals and interviews are also reliable sources that are often overlooked. These sources add more personal details to the daily activities and thoughts of the joint CubanCongolese rebels. In these historical artifacts we can find traces of a more fundamental issue. By looking for these details, we begin to develop a broader scope of the situation and weave together previous historical accounts.

In his article, Marc Jourdier relates a Cuban perception of the local rebels, stating the local Congolese "se niega a cavar trincheras porque los agujeros en la tierra son para los muertos y salen corriendo en cuanto se produce un choque serio." This is just one example of how the troops' ontological differences affected simple tasks and hindered the revolution. Guevara's Western guerrilla tactics, such as trench warfare, directly opposed the African worldview. He would have been more successful in leading and uniting the two forces had he taken the element of African spirituality into account. His lack of knowledge about the spiritual values of the Congolese led to frequent misunderstandings and misinterpretations of their actions. As Michela Wrong explains, "It all looked good on paper. But the Congolese regarded carrying heavy loads as below their dignity and would wander off, bored, when the Cubans tried to stage ambushes. Superstitious, they relied on 'dawa,' magic potions whipped up by witch doctors, for victory, emptying their magazines into the sky with eyes shut tight." Their lack of familiarity 
with the local rebels' spiritual reality caused Che and the Cuban troops to constantly underestimate the Congolese tribes, provoking mutual distrust and dissension among the allied forces.

Although Che's Marxist ideology seems similar to the local troops' belief in cooperation and collective responsibility, the rigidity of his Marxist beliefs did not appeal to the local rebels. The Congolese rebel leaders may have understood the implications of accepting Cuban support and, therefore, the ideology that motivated Guevara, but the local tribes had no desire to adopt a Marxist mentality. The Cuban troops' ideology differed greatly from the Congolese forces' causing them to remain divided.

Upon hearing Guevara's plans in the Congo, former Egyptian president Nassar "was astonished, warning Guevara not to become 'another Tarzan, a white man among black men, leading them and protecting them...it can't be done"' (Gott xxiii). Guevara's worldview can be used to explain why, even though he shared similar epistemological values, the Congolese tribes still considered him an outsider. His willingness to fight alongside them, and potentially die for their cause, was not enough to convince the Congolese that their conflicting perspectives could be overcome. If anything, it made them question Guevara's motives even more. When aspects of Guevara's worldview differed, there was misunderstanding; when aspects of his worldview aligned, there was mistrust.

\section{WHAT WOULD SUCCESS HAVE LOOKED LIKE?}

Guevara failed. But what does that mean? What would success have looked like? Based on his experiences in Cuba and Bolivia and his strong journaling habits, we have a pretty good idea of his intentions. Guevara was very persistent in creating space for underrepresented populations to control means of production, such as land and resources. His goal for the Congo, and all of Africa, was for Africans to create functioning, healthy governments and economies for themselves. Based on his previous experiences and writings, I do not believe that he would have stuck around to see these ideas realize. His mission was to capture the attention of the existing government, inspire agency among the locals, use his expertise to initiate their revolution, and allow locals to finish the job. He drew attention to global issues of inequality and injustice, while attempting to give locals the tools that they would need to correct them. Based on his own writings we know that he had several other countries in mind for future revolution. After securing a place at the table for local authority in the restructuring of the Congolese government, I believe that Che would have moved on to his next revolution. As we saw in Cuba, he became anxious and disheartened by staying and serving in political positions. Afterall, he opposed the bourgeoisie everywhere and called for "many Vietnams" (Guevara “Message”).

\section{CONCLUSION}

Ernesto "Che" Guevara's involvement in Africa is often eclipsed by his revolution and death in Latin America. Little research exists regarding his nine-month revolutionary campaign in the Congo and even less, if any, is available from African and Hispanic points of view. The little information available is in Guevara's personal Pasajes de la guerra revolucionaria: Congo or in texts which use the information from Che's "Congo Diary" to reconstruct the expedition. In the limited textual evidence of Guevara's presence in the Congo (often written from Western perspectives), many scholars have theorized as to why the Cubans failed in the Congo through a strictly political and economic approach. Some reasons include regionalism in the Congo, conflict between Congolese and Cuban rebel forces, insufficient resources, and a lack of a unified vision. However, these reasons can be interpreted on a more fundamental level. The Cubans', and more specifically Guevara's, opposing worldviews were the pivotal factor leading to divisiveness among the rebel forces in the Congo and the ultimate failure of their mission. Differentiating ideological, axiological, ontological, and epistemological values, led the Cubans to perceive "the morale and the competence of the Congolese rebels to be low" (Seddon). As for Guevara, instead of attempting to understand the allied African forces, he aspired to unify them according to his personal worldview which caused him to be regarded as "el hombre que soñaba con 'cubanizar a los congoleños"' (Jourdier). Che's lack of awareness and disregard for the way in which the Congolese interpreted their social world, the nature of their values and reality, and their knowledge processes led to divisiveness and mistrust at every level. This disunity inevitably precipitated the withdrawal of Cuban support and the Organisation of African Unity's willingness to negotiate with the Congolese government, resulting in Guevara's final abandonment of the Congo on November 20, 1965. 


\section{NOTES}

1 From Guevara's "Patria o muerte” address at the 1964 United Nations General Assembly in New York City.

2. Biographical information taken from Paco Ignacio Taibo II's Ernesto Guevara: También conocido como el Che (1996).

3. Transcript not provided by video. Transcribed manually.

4. Transcript provided by video.

\section{WORKS CITED}

Balakrishnan, Sarah. "The Afropolitan Idea: New Perspectives on Cosmopolitanism in African Studies." History Compass, vol. 15, no. 2, 2017, pp. 1-11.

--- "Afropolitanism and the End of Black Nationalism.” Routledge International Handbook of Cosmopolitanism Studies, Routledge, 2018, pp. 575-585.

Clark, John Frank. The African Stakes of the Congo War. New York: Palgrave Macmillan, 2002.

Dixon, Vernon J. “African-oriented and Euro-American-oriented world views: Research methodologies and economics." The Review of Black Political Economy, vol. 7, no. 7, 1977, pp. 119-156.

Gott, Richard. Introduction. The African Dream: The Diaries of the Revolutionary War in the Congo. Translated by Patrick Camiller, New York: Grove Press, 2000, pp. ix-xli.

Guevara, Ernesto Che. "Farewell Letter to Fidel Castro.” 1965, History of Cuba, historyofcuba.com/history/ cheltr.htm.

---. “Il piano e gli uomini.” Il Manifesto, no. 7, 1969.

---. "Message to the Tricontinental." Tricontinental Conference, Organization of Solidarity with the People of Asia, Africa and Latin America (OSPAAAL), January 1966, Havana, Cuba. Address. Che Guevara Internet Archive, 6 Oct. 2020, www.marxists.org/archive/guevara/1967/04/16. htm. Accessed 7 Oct. 2020.

---. Pasajes de la guerra revolucionaria: Congo. Buenos Aires: Editorial Sudamericana S.A., 1999.

---. "Patria o muerte.” General Assembly, United Nations, 11 Dec 1964, New York City. Address.

Jourdier, Marc. "El Che en el Congo: 'La historia de un fracaso'” The Nuevo Herald. Doral, FL: McClatchy Company, 21 Apr. 2015, www.elnuevoherald.com/noticias/mundo/ america-latina/cuba-es/article19138119.html. Accessed 7 Oct. 2020 .

Keita Carroll, Karanja. "Africana Studies and Research Methodology: Revisiting the Centrality of the Afrikan Worldview." Journal of Pan African Studies, vol. 2, no. 2, Mar.
2008, pp. 4-27.

Löwy, Michael. The Marxism of Che Guevara: Philosophy, Economics, Revolutionary Warfare. Lanham: Rowman \& Littlefield Publishers, 2007.

Mbembe, Achille. “Afropolitanism.” 2007. Journal of Contemporary African Art, Translated by Laurent Chauvet, no. 46, 2020, pp. 56-61.

---, and Sarah Balakrishnan. "Pan-African Legacies, Afropolitan Futures: A conversation with Achille Mbembe." Transition, vol. 120, 2016, pp. 28-37.

Monzón, Agustín. "El Che Guevara murió en el Congo.” El Independiente. Madrid, 10 July 2017, www.elindependiente.com/tendencias/2017/10/07/el-che-guevara-murio-enel-congo/. Accessed 7 Oct. 2020.

Richards, Dona. "Let the Circle Be Unbroken: The Implications of African-American Spirituality.” Présence Africaine, no. 117, 1981, pp. 247-292.

Seddon, David. "Che Guevara in the Congo.” Pambazuka News, 15 Dec. 2017, www.pambazuka.org/pan-africanism/ che-guevara-congo. Accessed 7 Oct. 2020.

Taibo II, Paco Ignacio. Ernesto Guevara: También conocido como el Che. 42nd ed. Ciudad De México: Planeta Mexicana, 1996.

"Tatu, el Che en el Congo - Tatu, il Che in Congo [DOCU CUBA]." ItaliaCubaNazionale, Mundo Latino, 1997. YouTube, www.youtube.com/watch?v=zzXsWKoaQeA

Villafaña, Frank. Cold War in the Congo: The Confrontation of Cuban Military Forces, 1960-1967. New Brunswick, N.J.: Transaction Publishers, 2009.

Wrong, Michela. “Che in Africa.” The New York Times, 11 Nov. 2001. Web. 